\title{
Cooking Qualities and Gelatinization Properties of Stored Akamai : Japanese Native Reddish Round Rice
}

\author{
Studies on Physical and Chemical Properties and \\ Taste Characteristic of Akamai. Part III
}

\author{
Ohy Chieko* and UmeKuni Tomoko* \\ Department of Home Economics, Tokyo Bunka Junior College \\ 6-38-1, Honcho, Nakano-ku, Tokyo 164-8638
}

\begin{abstract}
The gelatinization properties of cooked and stored Akamai were measured with RVA, and physical properties and sensory evaluation of gobugayu (gruel) were examined. Based on the RVA measurement results, Akamai with a milling yield of $95 \%$ showed a higher tendency of viscosity increase at the starting temperature than Sasanishiki, Haenuki and Akamai. Akamai immediately after cooking showed lower values in maximum, minimum and ending viscosities and breakdown than Haenuki, Sasanishiki and Akamai with a milling yield of $95 \%$. However, the decrease in viscosity by storage and salt addition was not observed. From these results, Akamai was considered able to be used with salt added seasoned cooked rice. Based on the results concerning physical properties of gobugayu (gruel), it was considered that Akamai with a milling yield of $95 \%$ was suitable for gobugayu (gruel) since its breaking energy and viscosity of omoyu (gruel liquid) were both low. In the sensory evaluation of gobugayu (gruel), Akamai with a milling yield of $95 \%$ was preferred in the total evaluation, while not preferred in viscosity.
\end{abstract}

(Received Jun. 6, 2001 ; Accepted Nov. 27, 2001)

We study physicochemical properties and application methods in order to extend the utilization range of Akamai, which is brown rice with a red coloring. In previous reports ${ }^{1) 22}$, the amylose content of Akamai is higher than that of Haenuki and Sasanishiki, and easily glutinized, its physical properties were hard and Akamai was a less glutinous rice. A Fr.III/Fr.II value of Akamai determined by gel filtration was as high as 3.6 when compared against at value of 2.9 for Haenuki and 3. 4 for Sasanishiki, and Akamai was not preferred significantly in the sensory evaluation on cooked rice. In this study, we examined the regelatinization characteristics of Akamai, which is as a result of the addition of salt. Further the application methods of
Akamai was examined compared to cooking methods from the viewpoint of gruel.

\section{Material and Methods}

\section{Samples tested and preparation of samples}

(1) Samples Akamai (Japanese native reddish round rice) grown in 1995 was obtained from the Okitama Agricultural Cooperaive of Yamagata Prefecture, similarly to the previous report ${ }^{11}$. For reference samples, Haenuki and Sasanishiki on the general grown in Yamagata Prefecture in 1995 was used. Akamai was milled to $90 \%$ milled rice (hereafter referred to as Akamai) and the other was done to $95 \%$ (hereafter referred to as Akamai with a milling yield of $95 \%$ ) using a milling machine 
(Toshiba Electric Co., Ltd., CRM-500type).

\section{(2) Preparation of samples $100 \mathrm{~g}$ of each} sample was washed 5 times with distilled water, 1.5 times distilled water was added to the weight of the rice, immersed in water for 30 minutes, and cooked with an electric rice cooker (Mitsubishi Electric Co., Ltd., J-R 5 T type). Cooked rice after steaming for 10 minutes was designated as just after cooking. Cooked rices were crushed and dehydrated with ethanol and acetone, then as dry powder placed on samples for the Rapid Visco Analyzer (RVA). Samples for the test were prepared according to 4 storage conditions : (1) just after cooking, (2) stored for 1 day at $80^{\circ} \mathrm{C}$, (3) stored for 3 days at $5{ }^{\circ} \mathrm{C}$, (4) stored for 1 week at $-20^{\circ} \mathrm{C}$. The rice which added $1 \% \mathrm{NaCl}$ was also similarly prepared. Then respectivly storaged for 1 week at $-20^{\circ} \mathrm{C}$. Cooked rice stored at $5{ }^{\circ} \mathrm{C}$ and $-20^{\circ} \mathrm{C}$ were treated for the test after heating on each side for 30 seconds with a microwave oven (manufactured by the Hitachi Corporation, MOR50700S type, 990W).

\section{Measuring method for Rapid Visco Analyzer} (RVA)

Samples prepared as described above were measured with a RVA (manufactured in Australia, RVA-3 D type). The measuring method followed that of TOYOShima et $a l^{3}$. Suspension samples prepared at $14 \%$ concentration for $3.5 \mathrm{~g}$ of sample were heated from $50^{\circ} \mathrm{C}$ to $93^{\circ} \mathrm{C}$ at 4 minutes, held for 7 minutes and cooled to $50^{\circ} \mathrm{C}$, held for 3 minutes.

\section{3 . Preparation of gobugayu (gruel)}

$50 \mathrm{~g}$ of rice were washed 5 times with distilled water, immersed for 30 minutes adding distilled water so that a total weight of rice and water equaled $650 \mathrm{~g}$, and cooked by a kayu (gruel) mode of an electric rice cooker (RCK- 5 DM type).

\section{Measurement of physical properties of gobugayu (gruel)}

(1) Breaking strength analysis on gruel

1 ) Breaking strength analysis in a stenless steal petri dish:A breaking strength analysis on kayu (gruel) was carried out using a Reoner RE3305 type testing equipment manufactured by Yamaden.

The stenless steal petri dish was $15 \mathrm{~mm}$ high and $40 \mathrm{~mm}$ in diameter, and contained $10 \mathrm{~g}$ of kayu (gruel) and $10 \mathrm{~g}$ of omoyu (gruel liquid). A plunger was $20 \mathrm{~mm}$ in diameter, $10 \mathrm{~mm}$ in compression, a loading cell was $20 \mathrm{~kg}, 10 \mathrm{~mm} / \mathrm{sec}$ in velocity, and temperature of gobugayu (gruel) was set at $20^{\circ} \mathrm{C}$.

2 ) Breaking strength analysis on one grain of kayu (gruel) : A plunger was a wedge type $1 \mathrm{~mm}$ at a tip, $99 \%$ in rate of strain, a loading cell was $2 \mathrm{~kg}$ and $1 \mathrm{~mm} / \mathrm{sec}$ in velocity.

\section{( 2 ) Viscosity of omoyu (gruel liquid)}

Viscosity of omoyu was measured at $20^{\circ} \mathrm{C}$ with a $\mathrm{BL}$ type rotary viscometer. No. 1 and No. 2 rotors were used at $6,12,30$ and $60 \mathrm{rpm}$.

\section{5 . Sensory evaluation on gobugayu (gruel)}

Sensory evaluation of 4 kinds of gobugayu was performed with the rating method ${ }^{4)}$. Scores using the scale from -3 to +3 . Panel members were 13 in total consisting of students of the Department of Home Economics and teachers of the Tokyo Bunka Junior College. A sensory evaluation was carried out on the analytic type and the preference type. For the analysis, significant differences were tested between samples and panelers.

\section{Results and Discussion}

\section{Measurement Results of RVA}

The RVA measurement results on various cooked rice samples immediately after cooking are shown in Table1. The viscosity increase temperature was in the order of lower values, $63.5^{\circ} \mathrm{C}$ for Sasanishiki, 69. $3^{\circ} \mathrm{C}$ for Haenuki, $71.3^{\circ} \mathrm{C}$ for Akamai, $80.3^{\circ} \mathrm{C}$ for Akamai with a milling yield of $95 \%$, and that of Akamai with a milling yield of $95 \%$ was transferred to a higher temperature side by $9 \sim 17^{\circ} \mathrm{C}$. This was considered because adhered rice bran prevented glunination of rice. For peak and lowest viscosities, breakdown, final viscosity and consistency, Haenuki showed the largest values, followed by the order of Sasanishiki, Akamai with a milling yield of $95 \%$ and Akamai. In general, it is said that the maximum viscosity and breakdown, taste is better ${ }^{5) \sim 6}$. Toyoshima et $a l^{3}$, reported that a high ending viscosity in viscosity measurement of rice flour indicated rice which hardened when cooled. The author reported in the previous report ${ }^{1)}$, based on the RVA measurement on rice flour, that Akamai 
Table 1 R.V.A of various cooked rices

\begin{tabular}{lcccc}
\hline & Akamai & $\begin{array}{c}\text { Akamai with } \\
\text { a milling } \\
\text { Yield of } 95 \%\end{array}$ & Haenuki & Sasanisiki \\
\hline Viscosity rising temperature $\left({ }^{\circ} \mathrm{C}\right)$ & 71.3 & 80.3 & 69.3 & 63.3 \\
Maximum viscosity (RVU) & 128 & 160 & 348 & 243 \\
Temperature of maximum viscosity $\left({ }^{\circ} \mathrm{C}\right)$ & 93 & 93 & 93 & 93 \\
Minimum viscosity (RVU) & 116 & 140 & 224 & 192 \\
Break down (RVU) ${ }^{*}$ & 12 & 20 & 124 & 51 \\
Ending viscosity at $50^{\circ} \mathrm{C}(\mathrm{RVU})$ & 160 & 193 & 393 & 324 \\
Consistency (RVU) ${ }^{* *}$ & 44 & 53 & 169 & 132 \\
\hline
\end{tabular}

* Maximum viscosity - Minimum viscosity

** Ending viscosity at $50^{\circ} \mathrm{C}-$ Minimum viscosity
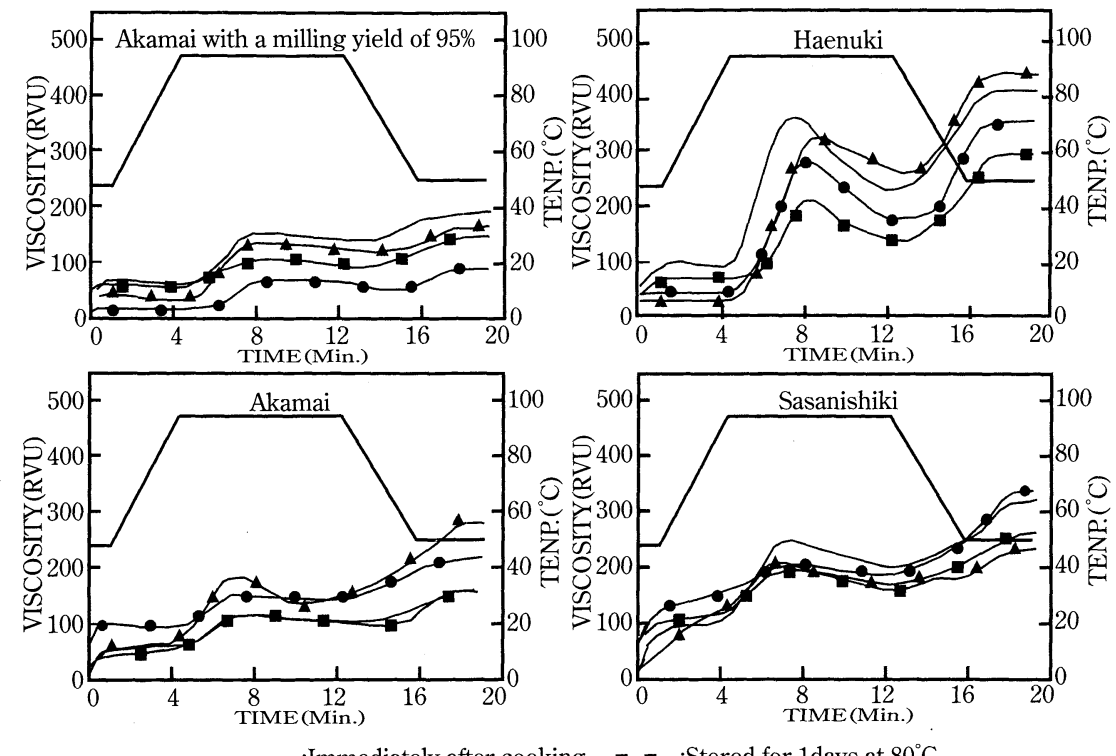

$\_$: : Stored for 3 days at $5{ }^{\circ} \mathrm{C}$,

- Stored for 1 days at $80^{\circ} \mathrm{C}$

$\rightarrow \longrightarrow$ :Frozen for 1 week at $-20^{\circ} \mathrm{C}$

Fig. 1 RVA Viscograms of each storage cooked rices

with a milling yield of $95 \%$ and Akamai had a high ending viscosity, and Haenuki and Sasanishiki had a low ending viscosity. Cooked rice samples of high ending viscosity measured by RVA in this study were Haenuki and Sasanishiki, followed by Akamai with a milling yield of $95 \%$ and Akamai, showing a reverse tendency to rice flour. It was found that cooked rice of higher ending viscosity was more viscous and softer. Next, viscosity curves by the type of storage are shown in Fig. 1. For 3 samples of
Akamai with a milling yield of $95 \%$, Haenuki and Sasanishiki were all markedly lower maximum viscosity and breakdown by storage. On the other hand, viscosity of samples of Akamai immediately after cooking and those stored for 1 day at $80^{\circ} \mathrm{C}$ were almost the same. The maximum viscosities of samples stored for 3 days at $5{ }^{\circ} \mathrm{C}$ and those stored for 1 week at $-20^{\circ} \mathrm{C}$ were higher than those of immediately cooked, and breakdown showed an increased tendency. The reason for this was 
considered because cooked Akamai became hard as a result of cooking with the same amount of water and the reheating effect of using a microwave oven. The $5^{\circ} \mathrm{C}$ stored Akamai cooked rice lowered viscosity, and it became retrogradate because the water during the liquid phase entered the hydrogen bond, and it was presumed that the hydrogen bond was collapsed by reheating, then the viscosity rose in the Akamai, because the etanol changed the Akamai into the dehydrated powder. In the storage of $-20^{\circ} \mathrm{C}$, the water of rice starch became perfectly crystalized, and ther was no change of the properties, and in addition, it became difficult to achieve the hydrogen bond. Reheating hindered retrogradation. The results of the effect of salt addition are shown in Fig. 2. Though the decrease in maximum, minimum and ending viscosities were observed by salt addition for Akamai with a milling yield of 95\%, Haenuki and Sasanishiki. Akami was slightly increased in viscosity, to the contrary, by salt addition. The reason was considered to be that Akamai was low in water absorption rate and tended to lead incomplete dissociation of $\mathrm{NaCl}$. Further examination will be necessary. Based on the results of this study, Akamai was considered in cooking to be suited for seasoned rice dishes with salt taste rather than plain milled cooked rice.

\section{Measurement Results on Physical Properties of Gobugayu}

The measurement results on breaking energy of gobugayu (gruel) are shown in Fig. 3, 4. For breaking energy in stenless steal petri dish, Akamai showed the largest value, followed by Akamai with a milling yield of $95 \%$, Haenuki, and Sasanishiki showed the smallest value.Breaking curve of Gobugayu in a dish Akamai with a milling yield of $95 \%$ was similar with Haenuki and Sasanishiki. On the other hand, the breaking force of Akamai was bigger than other three kinds. For breaking energy of one grain of kayu (gruel), Akamai with a milling yield of 95\% showed the smallest energy value, followed by Akamai, Haenuki, and Sasanishiki showed the largest energy value, and the breaking energy showed a different tendency from a combination of kayu (gruel) and omoyu (gruel liquid). When breaking curve in one grain of Gobugayu, Akamai with a milling yield of $95 \%$ was the biggest breaking force until $75 \%$ strain, but therafter, Akamai was the biggest breaking force. In order to clarify the reason for this difference, viscosity of omoyu (gruel
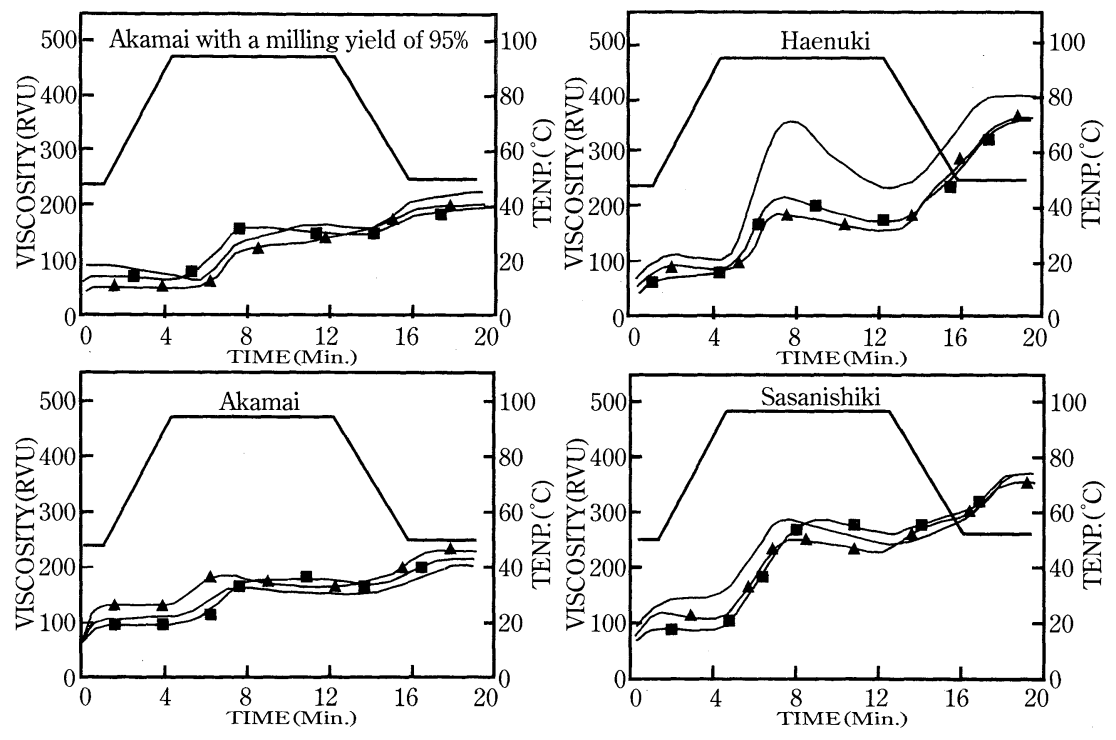

— :Immediately after cooking of no addition,

— Frozen for 1 week at $-20^{\circ} \mathrm{C}$ of salt addition

:Immediately after cooking of salt addition

Fig. 2 RVA Viscograms of each storage of salt addition cooked rices 


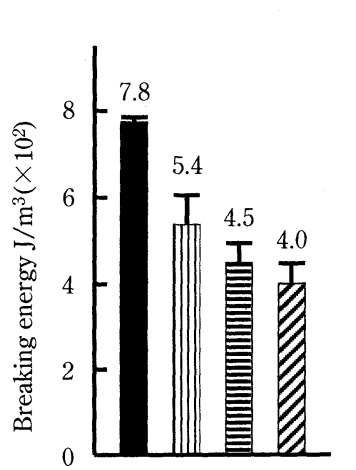

In case

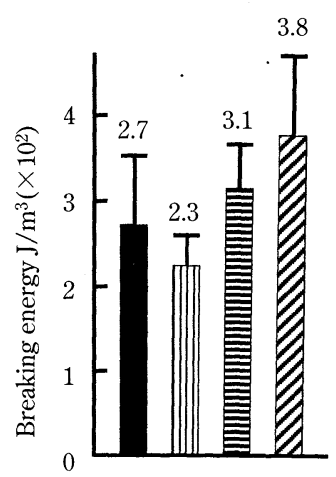

1 grain
:Akamai, [I]III :Akamai with a milling yield of 95\%

”:Haenuki, $\mathbb{Z}$ :Sasanishiki

Fig. 3 Breaking energy of gobugayu

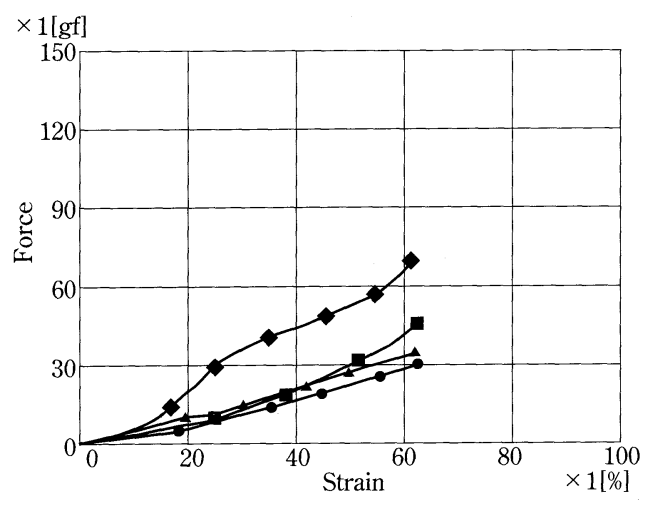

In case
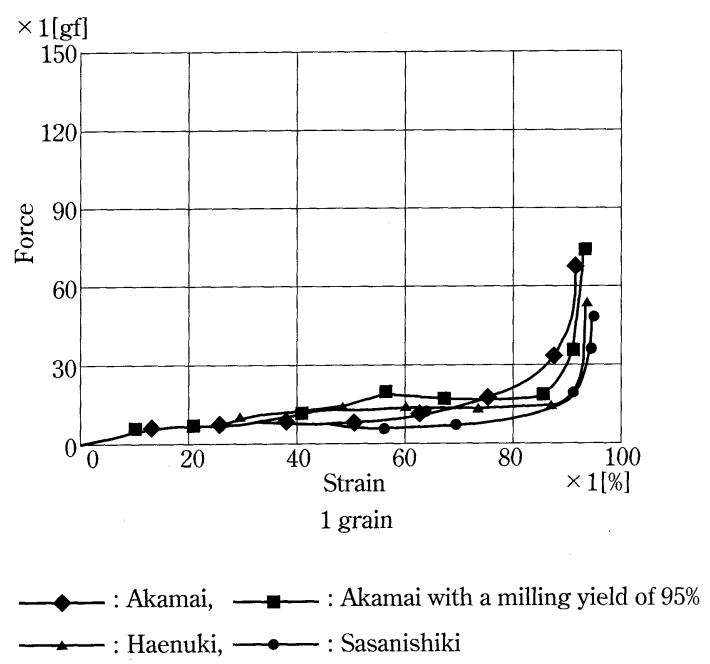

Fig. 4 Breaking curves of gobugayu liquid) was measured. Fig. 5 shows apparent viscosities of omoyu (gruel liquid). Though omoyu of Akamai showed a viscosity almost as high as 100 times compared with other 3 rice samples, this reason was considered to be caused by difficult dissolution of starch since swelling of starch was controlled by rice bran remaining half in Akamai with a milling yield of $95 \%$. In the previous report ${ }^{1)}$, it was considered that the viscosity of omoyu increased since Akamai was high in iodine color reaction and rich in dissolved solid matter. It guessed that Akamai was many amylose content and easy to gel, and then, in the equal concentration of Omoyu which the viscosity of Akamai gruel was high and hardness. It guessed that there was the hardness of Omoyu because of the elution of the amylose, and it remained the brittleness when it was chilled.It proved that Kayu of Akamai with a milling yield of $95 \%$ whose viscosity of gruel liquid was suppressed, and the physical property of whole gruel was similar to Haenuki and Sasanishiki.

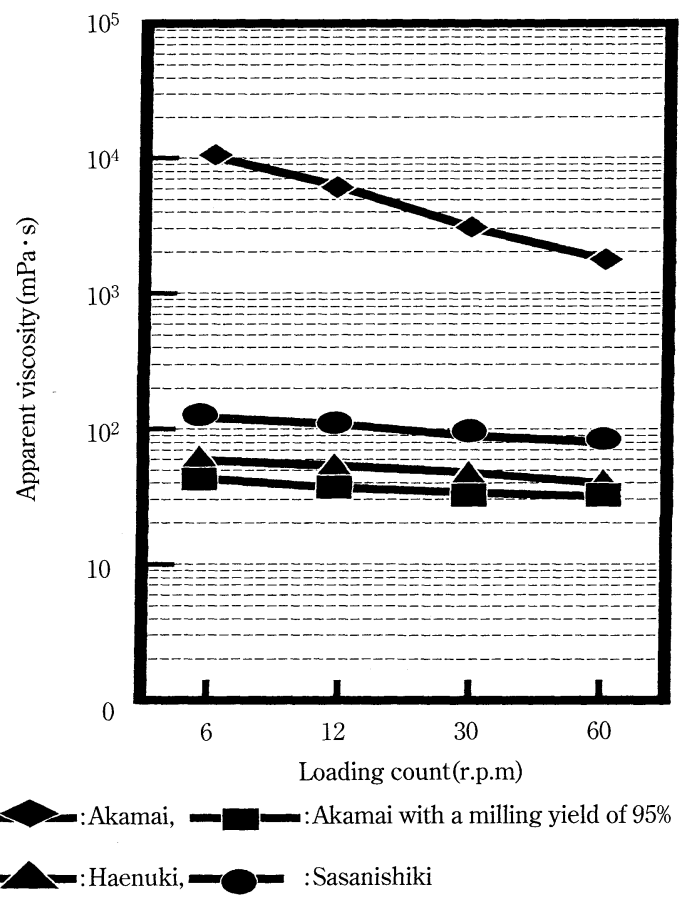

Fig. 5 Apparent viscosities of omoyu 
Considering cooking suitability, when Akamai is eaten as gobugayu, Akamai with a milling yield of 95\% has more advantages than Akamai because of suppressed viscosity and pink coloration of rice bran remaining in Akamai with a milling yield of $95 \%$.

\section{Sensory Evaluation Results of Gobugayu}

Fig. 6 shows the sensory evaluation results of gobugayu. For the analysis type, viscosity, color and luster was observed a significant difference of $1 \%$. For preference type, significant differences were observed in viscosity of $1 \%$, and in color, luster and total evaluation with signifficant differences of $5 \%$, and Akamai with a milling yield of $95 \%$ was preferred in total evaluation, though not preferred viscosity.

Gobugayu using the Akamai with a milling yield of $95 \%$ conbnues in Kyoto. The result of the present experiment proved that it is a given that Akamai with a milling yiled of $95 \%$ was suitable for gobugayu.

\section{Abstract}

The gelatinization properties of cooked and stored Akamai were measured with RVA, and physical properties and sensory evaluation of gobugayu (gruel) were examined. The results are as follows:
(1) Based on the RVA measurement results, Akamai with a milling yield of $95 \%$ showed a higher tendency of viscosity increase at the starting temperature than Sasanishiki, Haenuki and Akamai. Akamai immediately after cooking showed lower values in maximum, minimum and ending viscosities and breakdown than Haenuki, Sasanishiki and Akamai with a milling yield of $95 \%$. However, the decrease in viscosity by storage and salt addition was not observed. From these results, Akamai was considered able to be used with salt added seasoned cooked rice.

(2) Based on the results concerning physical properties of gobugayu (gruel), it was considered that Akamai with a milling yield of 95\% was suitable for gobugayu since its breaking energy and viscosity of omoyu (gruel liquid) were both low.

(3) In the sensory evaluation of gobugayu, Akamai with a milling yield of $95 \%$ was preferred in the total evaluation, while not preferred in viscosity.

A summary of this study was presented at the annual meeting of the Japan Society of Cookery Science in September, 2000.

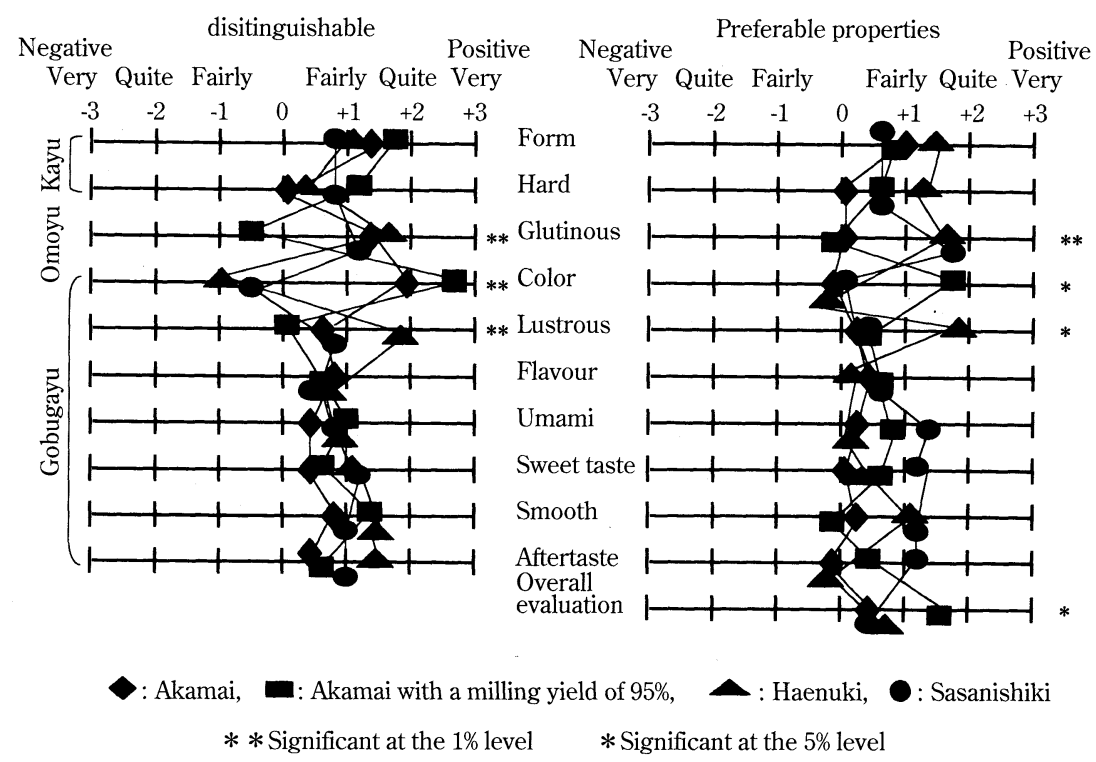

Fig. 6 Average qualities of gobugayu by the scoring method 


\section{References}

1 ) OHyA, C.: Bulletin of Yonezawa Women's College of Yamagata Pre., 33, 109 116 (1998)

2 ) Онуа, C. : Japan Associ. Food Preserva. Scien., 26, 139 143 (2000).

3 ) Toyoshima, H., OKadome, H., Ohstubo, K., Shudou, M., Horishue, N., Inazu, O., Narizuka, A., Aizaki, M., OHKawa, T., Inouti, N. and Fuwa, H. : Japan Socie. Food Scien. Techn., 44, 579 584 (1997)

4 ) Yoshikawa, S. and Satou, S. : Measurement of Quality at Food (Kourin Shoin), p. 80 (1961)

5 ) Chikubu, S., Watanabe, S., Sugimoto, T., Sakai, F. and TANIGUTI, Y.: Japanese Socie. Applied Glucoscien., 30, 333 (1983)

6) Chikubu, S., Watanabe, S., Sugimoto, T., Manabe, N., Sakai, F. and TANiguti, Y.: Japanese Socie. Applied Glucoscien., 32, 51 (1985)

\section{赤米の調理特性と保存による糊化特性}

赤米の理化学的性質と 食味特性に関する研究（第 3 報）

\author{
大家千恵子* ・梅国智子* \\ *東京文化短期大学家政科 \\ （テ164-8638 東京都中野区本町 6-38-1）
}

赤米を炊飯し保存したときの糊化特性をRVAで測 定し, さらに五分张物性と官能評価を検討した。赤

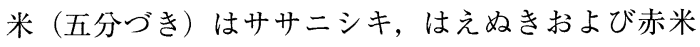
(白米)に比べ, 粘度上昇開始温度が高かった。赤米 (白米) は炊飯直後で, はえぬき, ササニシキ, 赤米 (五分づき) よりも最高, 最低, 最終粘度掞よびブレ ークダウンが最も低い結果であった。しかし, 保存お よび塩類添加による粘度低下はみられなかった。この ことより, 赤米 (白米) は塩類添加した味付け飯に適 用できると考えられた。赤米（五分づき）を用いた五 分强は破断エネルギーおよび重湯の粘度が低く抑えら れ, 官能評価の総合評価でも好まれ, 五分张として適 していると考えられた。

(平成13年 6 月 6 日受付, 平成13年11月 30 日受理) 